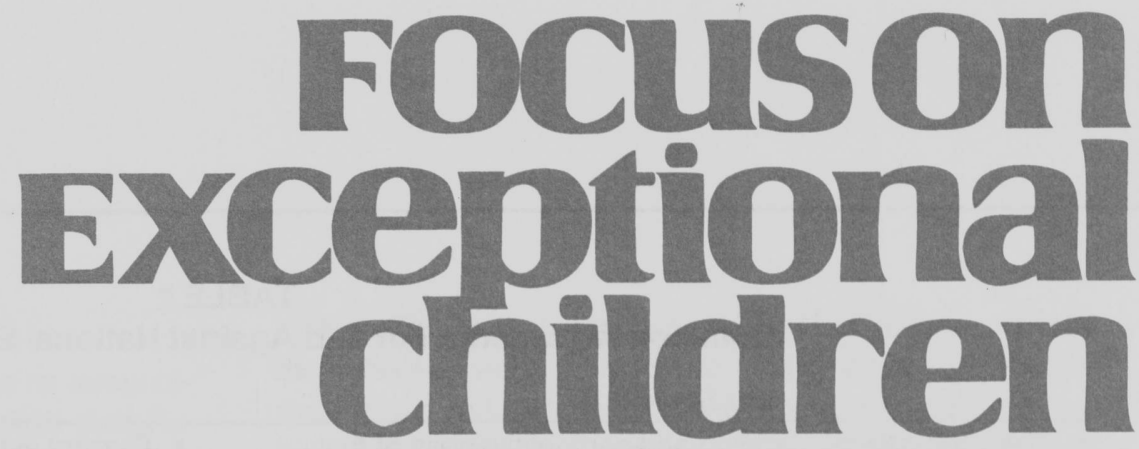

\title{
Standards for All American Students
}

\author{
James G. Shriner, James E. Ysseldyke, and Martha L. Thurlow
}

Unless you are setting standards these days, you seem to be out of sync with the field of education. A frenetic pace in the endeavor to set and refine standards is the norm for national groups in all academic content areas, health and physical education, the arts, and vocational education. National-level efforts, in turn, are picked up by most state education agencies, and by intermediate and local school districts. The national efforts alone have a combined budget of almost $\$ 10$ million (Viadero, 1993). It is big business and high stakes for the entire educational community of the United States. After defining what standards are, and why they are important, we will summarize the standards-setting activities currently underway and give extended examples from mathematics and science. We will explain how and why these efforts are likely to affect all educators, including special educators, and all students, with and without disabilities.

\section{THE WHAT AND WHY OF STANDARDS}

\section{Definition}

Standards are statements of criteria against which comparisons can be made (Ysseldyke, Thurlow, \& Shriner, 1992). They are often value statements about what is important, and they are sometimes established for the purpose of changing an existing situation. Standards may be considered exemplars or criteria that are used to measure the quantity or quality of something. In some cases a standard is a threshold value - the lowest score acceptable for a given decision. The definition of the term "standard," therefore, may seem relatively straightforward. Within the field of education, however, the term becomes nebulous, with many different interpretations and applications.

\section{Why Standards?}

The perceived need to change the American educational system fostered by reports from the early 1980s (e.g., A Nation at Risk, National Commission on Excellence in Education, 1983) is precisely the impetus behind the standards-setting efforts. Major activities began in the late 1980s and likely will continue through most of this decade. Arguments for and against setting national standards were summarized in a report by the National Council on Education Standards and Testing (NCEST) (1992). Table 1 is a listing of the major points raised by NCEST. Because well established efforts to set standards in most content areas already exist, arguments against standards have become challenges with which the standardssetting groups must deal. For example, most content-area groups are addressing, as an eq-

James Shriner is a Senior Researcher, James Ysseldyke is Director, and Martha Thurlow is Assistant Director, National Center on Educational Outcomes, University of Minnesota. 
TABLE 1

\section{Common Arguments For and Against National Education Standards}

For Standards

- The international standing and competitiveness of the U. S. economy, system of security, and diplomatic influence require national attention to develop the nation's human capital.

- Standards will help assure that our population will have the knowledge and values to make our democracy work.

- Standards will provide challenging goals and criteria for the allocation of scarce resources to improve schools and teacher development.

- Standards will reinforce the equality of educational opportunity that applies to all children across the nation.

- Standards will encourage states and localities to raise their educational expectations.

- Because states only have limited resources, a national approach would be far more efficient.
Against Standards

- Current established standards tend to drag down the system in certain areas. Any national standards would affect the entire system.

- If standards are developed, but the resources and strategies to put them into effect are not, the nation's students will suffer.

- Any new standards developed would draw attention away from the many successful state and local reforms that now exist.

- Developing new standards would require a new curriculum, stifling any state and local creativity and initiative.

- New standards would require a single common set of educational standards that would be impossible to meet with the cultural and ethnic diversity of our nation.

Source: National Council on Education Standards and Testing, 1992, Raising Standards for American Education (Washington, DC: U. S. Government Printing Office).

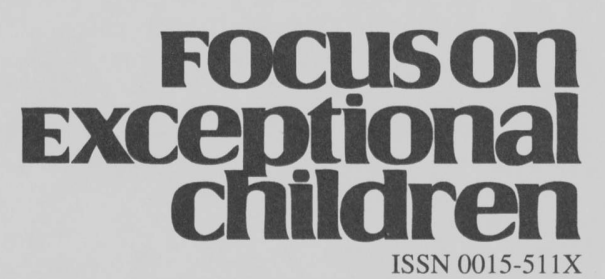

FOCUS ON EXCEPTIONAL CHILDREN (USPS 203-360) is published monthly except June, July, and August as a service to teachers, special educators, curriculum specialists, administrators, and those concerned with the special education of exceptional children. This publication is annotated and indexed by the ERIC Clearinghouse on Handicapped and Gifted Children for publication in the monthly Current Index to Journals in Education (CIJE) and the quarterly index, Exceptional Children Education Resources (ECER). It is also available in microfilm from Xerox University Microfilms, Ann Arbor, MI. Subscription rates: Individual, $\$ 30$ per year; institutions, $\$ 40$ per year. Copyright (C) 1994, Love Publishing Company. All rights reserved. Reproduction in whole or part without written permission is prohibited. Printed in the United States of America. Second class postage is paid at Denver, Colorado. POSTMASTER: Send address changes to:

$$
\begin{aligned}
& \text { Love Publishing Company } \\
& \text { Executive and Editorial Office } \\
& 1777 \text { South Bellaire Street } \\
& \text { Denver, Colorado } 80222 \\
& \text { Telephone (303) 757-2579 }
\end{aligned}
$$

Edward L. Meyen

University of Kansas

Richard J. Whelan

University of Kansas Medical Center

Stanley F. Love

Publisher
Glenn A. Vergason Georgia State University

Holly T. Rumpler Senior Editor uity/fairness issue, the notion that a single set of standards would be incapable of serving the nation's diverse population adequately.

Most standards-setting activities serve as a focal point of a myriad of reform initiatives. Standards setting is a way to link local, state, and national education agencies and groups in discussion and planning about how to improve the educational outputs of the nation's schools. Standards setting also is a means to get professionals within and across disciplines to communicate with one another and with the public about what is important in preparing students for life in the next century. Most efforts to set standards are intradisciplinary (e.g., within mathematics), yet attempts are being made to bridge the many activities now occurring. In fact, the U. S. Congress has become involved in the process through legislation aimed at providing some guidance to and consistency across standards activities.

As part of the federal education reform legislation, Goals 2000: Educate America Act (U. S. Senate, 1993), a council will be formed to oversee all standards activities. This body, the National Education Standards and Improvement Council (NESIC), will certify the validity, reliability, and fairness of standards prepared by national and state-level groups. NESIC also will approve assessment strategies included in these activities. In addition, a Forum on Standards at the College Board in New York has been formed to look at how the individual standards activities can be put together to provide a coherent overall curriculum. Involvement of the federal government is discussed in greater detail later in this article. 


\section{Types of Standards}

Although educators sometimes cannot agree on terminology for standards-setting activities, and often more than one name is applied to the same or similar concept, three frequently used categories of standards are: (a) content standards, (b) performance standards, and (c) delivery standards. Standards also may be applied at different levels of the educational system. Table 2 is a matrix of each type of standard matched to different levels of applicability or interest. Examples of existing or possible combinations are listed.

\section{Content Standards}

Most of the discussion these days is about content standards, or statements of a necessary and desirable core of knowledge. Selden (1992) defined content standards as "descriptions of the knowledge and skills students are expected to learn in particular subject areas-and, thus, that schools are expected to teach" (p. 3). Professionals involved in all of the major subject areas, from the arts to social studies, have efforts underway to define, develop, or implement content standards within the discipline (see Table 3).

Content standards typically are developed by groups of subject-area experts who seek input from teachers, business, and community leaders. The process of defining content standards usually relies on the publication of a series of proposed standards to which invited and interested persons or groups may respond. The review and feedback process is used in order to establish some consensus about what is important to know for students in a particular subject area.

An area of interest that is getting increased attention is the development of "skill standards." Skill standards are a specific type of content standard that focuses on the needs of individuals entering the workforce. The impetus for skill standards draws largely from work done by the office of the Secretary of Labor. The Secretary's Commission on Achieving Necessary Skills (SCANS) proposed stronger initiatives for improving the skills of the American workforce (Secretary's Commission on Achieving Necessary Skills, 1992). This call has resulted in the proposal of the National Skill Standards Act of 1993, part of the Goals 2000 legislation. Under the Act, a Board, called the National Skills Standards board, would be established to stimulate the development of skill standards. The board would be composed of representatives from the federal government, education, business and industry, labor, and state government. Efforts of the board would be directed toward identifying broad occupationally organized clusters of skill standards that could be measured through a related assessment system. The skill standards could be used then to enhance the school-to-work programs in which non-college-bound students are trained for employment, and they provide a vehicle for students to determine and show evidence of skills in which they are (or need to be) competent. Employers also would be provided assistance in evaluating the skills of potential employees.

Skill standards are just as controversial, if not more so, than other types of standards. Olson (1993) cited the following concerns:

Too much federal involvement in standards activities

$\checkmark$ Inadequate representation of industry on the proposed board

Uncertainty about development and use of the standards

Possible increased barriers to the hiring of women and minorities

The federal involvement issue is significant because skill standards are being proposed from within the government. Some concern has been raised over the name of the proposed group (National Skills Standards Board) because a national board suggests mandated, not voluntary, standards. One suggested alternative has been to call the group an Advisory Commission and to reinforce the voluntary nature of the standards that are developed (Olson, 1993).

In addition, equity and civil rights concerns are especially crucial to people in groups that traditionally have been underrepresented in the high-skill jobs for which the standards will be geared. The effect of potential certification in skills competencies has important ramifications for individuals with disabilities, disadvantaged students, and members of minority groups. Advocates for these groups have raised concerns as to just how such a certificate system might be used.

Still, the fact remains that the United States is the only major country not to have a comprehensive plan linking the educational system with the business and industry community. The notion that we need skill standards rests upon the perception that American workers need better training and work skills to keep the nation competitive in the world market (U. S. Congress, 1993). Establishing skill standards is also the only major effort under the proposed system that addresses nonacademic skills-those not geared toward college-bound students. Realistically, for students with disabilities, skill standards may offer a means to demonstrate acquired competencies that will be of value to potential employers. Including standards for skills and assessments out- 
TABLE 2

Examples of Three Types of Standards at Different Levels of Application

Type of Standard

Level of Tontent Delivery or

Application Content Performance Opportunity-to-Learn (Inputs)

Individual

- Course Selection

- Graduation Requirements

- IEP (Method)

- Individualized

- IEP Goals

Education Plan

- Individualized Family Service Plan

$\begin{array}{ll}\text { Classroom } & \text { Grade-level } \\ \text { Learner Outcomes }\end{array}$

- Mastery Learning Guide

- Teacher Evaluation Scales

- Instructional Ecology Analysis

Building

- Building Priorities

- Mastery Learning Guide

- Leadership Evaluation (Principals)

\begin{tabular}{|c|c|c|c|}
\hline District & $\begin{array}{l}\text { - District } \\
\text { Objectives/Goals }\end{array}$ & $\begin{array}{l}\text { - Graduation } \\
\text { Requirements }\end{array}$ & $\begin{array}{l}\text { - Teacher and Leadership } \\
\text { Evaluations }\end{array}$ \\
\hline
\end{tabular}

- Course Offerings

\begin{tabular}{|c|c|c|c|}
\hline \multirow[t]{3}{*}{ State } & $\begin{array}{l}\text { - State-approved } \\
\text { Outcomes }\end{array}$ & $\begin{array}{l}\text { - Graduation } \\
\text { Requirements }\end{array}$ & $\begin{array}{l}\text { - Licensure/Certification } \\
\text { Criteria }\end{array}$ \\
\hline & - Curricular Frameworks & - State Report Cards & - Vocational Education \\
\hline & $\begin{array}{l}\text { - Vocational Education } \\
\text { Standards }\end{array}$ & & Standards \\
\hline \multirow[t]{4}{*}{ National } & - Content-Area Standards & \multirow{2}{*}{$\begin{array}{l}\text { - National Assessment of } \\
\text { Educational Progress } \\
\text { Proficiency Levels }\end{array}$} & \multirow{2}{*}{$\begin{array}{l}\text { - National Board for } \\
\text { Professional Teaching } \\
\text { Standards }\end{array}$} \\
\hline & - National Skill Standards & & \\
\hline & & \multirow{2}{*}{$\begin{array}{l}\text { - National Council on } \\
\text { Education Standards and } \\
\text { Testing }\end{array}$} & $\begin{array}{l}\text { - Content-Area Teaching } \\
\text { Standards }\end{array}$ \\
\hline & & & $\begin{array}{l}\text { - National Opportunity-to-Learn } \\
\text { Standards }\end{array}$ \\
\hline \multirow[t]{2}{*}{ International } & & $\begin{array}{l}\text { - International Assessment of } \\
\text { Educational Progress } \\
\text { Proficiency Levels }\end{array}$ & \multirow{2}{*}{$\begin{array}{l}\text { - International Assessment of } \\
\text { Educational Progress- } \\
\text { School Environment } \\
\text { Variables }\end{array}$} \\
\hline & & $\begin{array}{l}\text { - Office of Economic } \\
\text { Cooperation and } \\
\text { Development Indicators }\end{array}$ & \\
\hline
\end{tabular}


TABLE 3

National Standards Setting Efforts

\begin{tabular}{|c|c|c|c|}
\hline Area & Contact & Participants & Completion \\
\hline Arts & $\begin{array}{l}\text { Music Educators National } \\
\text { Conference } \\
1902 \text { Association Dr. } \\
\text { Reston, VA } 22091\end{array}$ & $\begin{array}{l}\text { - American Association of } \\
\text { Theatre Education } \\
\text { - Music Educators National } \\
\text { Conference } \\
\text { - National Art Education } \\
\text { Association } \\
\text { - National Dance Association }\end{array}$ & $\begin{array}{l}\text { Drafts: } 1993 \\
\text { Final: } 1994\end{array}$ \\
\hline Civics & $\begin{array}{l}\text { Center for Civic Education } \\
5146 \text { Douglas Fir Rd. } \\
\text { Calabasas, CA } 91302-1467\end{array}$ & - Center for Civic Education & $\begin{array}{l}\text { Drafts: } 1993 \\
\text { Final: } 1994\end{array}$ \\
\hline Economics & $\begin{array}{l}\text { National Council on } \\
\text { Economic Education } \\
432 \text { Park Ave. South } \\
\text { New York, NY } 10016\end{array}$ & $\begin{array}{l}\text { - National Council } \\
\text { for Economics } \\
\text { Education }\end{array}$ & Final: 1997 \\
\hline English & $\begin{array}{l}\text { Center for the Study of } \\
\text { Reading } \\
174 \text { Children's Research } \\
\text { Center } \\
51 \text { Getty Dr. } \\
\text { Champaign, IL } 61820\end{array}$ & $\begin{array}{l}\text { - International Reading } \\
\text { Association } \\
\text { - National Council of } \\
\text { Teachers of English } \\
\text { - Center for the Study } \\
\text { of Reading }\end{array}$ & Final: 1994 \\
\hline Foreign Languages & $\begin{array}{l}\text { American Council on the } \\
\text { Teaching of Foreign } \\
\text { Languages } \\
6 \text { Executive Plaza } \\
\text { Yonkers, NY 10701-6801 }\end{array}$ & $\begin{array}{l}\text { - American Council on the } \\
\text { Teaching of Foreign } \\
\text { Languages } \\
\text { - American Association of } \\
\text { Teachers of French } \\
\text { - American Association of } \\
\text { Teachers of German } \\
\text { - American Association of } \\
\text { Teachers of Spanish and } \\
\text { Portuguese }\end{array}$ & Final: 1996 \\
\hline
\end{tabular}


TABLE 3-National Standards Setting Efforts (continued)

\begin{tabular}{|c|c|c|c|}
\hline Area & Contact & Participants & Completion \\
\hline Geography & $\begin{array}{l}\text { National Council for } \\
\text { Geographic Education } \\
1600 \text { M St. NW } \\
\text { Suite } 4200 \\
\text { Washington, DC } 20036\end{array}$ & $\begin{array}{l}\text { - National Council for } \\
\text { Geographic Education } \\
\text { - American Geographical } \\
\text { Society } \\
\text { - National Geographic Society } \\
\text { - Association of American } \\
\text { Geographers }\end{array}$ & $\begin{array}{l}\text { Drafts: } 1993 \\
\text { Final: } 1993\end{array}$ \\
\hline History & $\begin{array}{l}\text { National Center for History } \\
\text { in the Schools } \\
\text { University of California at } \\
\text { Los Angeles } \\
10880 \text { Wilshire Blvd. } \\
\text { Suite } 1610 \\
\text { Los Angeles, CA } 90024\end{array}$ & $\begin{array}{l}\text { - National Center for } \\
\text { History in the Schools }\end{array}$ & $\begin{array}{l}\text { Drafts: } 1993 \\
\text { Final: } 1994\end{array}$ \\
\hline Mathematics & $\begin{array}{l}\text { National Council of } \\
\text { Teachers of Mathematics } \\
1906 \text { Association Dr. } \\
\text { Reston, VA } 22091\end{array}$ & $\begin{array}{l}\text { - National Council of } \\
\text { Teachers of Mathematics }\end{array}$ & $\begin{array}{l}\text { Curriculum and } \\
\text { Evaluation, 1989; } \\
\text { Professional } \\
\text { Teaching Standards, } \\
\text { 1991; Assessment } \\
\text { Standards } \\
\text { (Draft 1993) }\end{array}$ \\
\hline Physical Education & $\begin{array}{l}\text { National Association for } \\
\text { Sport and Physical } \\
\text { Education } \\
1900 \text { Association Dr. } \\
\text { Reston, VA } 22091\end{array}$ & $\begin{array}{l}\text { - National Association for } \\
\text { Sport and Physical } \\
\text { Education }\end{array}$ & Final: 1994 \\
\hline Science & $\begin{array}{l}\text { National Research Council } \\
2101 \text { Constitution Ave. NW } \\
\text { HA } 486 \\
\text { Washington, DC } 20418\end{array}$ & $\begin{array}{l}\text { - National Research Council } \\
\text { - National Academy of } \\
\text { Sciences }\end{array}$ & $\begin{array}{l}\text { Drafts: } 1993 \\
\text { Final: } 1994\end{array}$ \\
\hline Social Studies & $\begin{array}{l}\text { National Task Force for } \\
\text { Social Studies Standards } \\
\text { National Council for the } \\
\text { Social Studies } \\
3501 \text { Newark St. NW } \\
\text { Washington, DC } 20016\end{array}$ & $\begin{array}{l}\text { - National Council for the } \\
\text { Social Studies }\end{array}$ & $\begin{array}{l}\text { Drafts: } 1993 \\
\text { Final: } 1994\end{array}$ \\
\hline
\end{tabular}


side of the traditionally academic world is viewed as an important safeguard against the "narrowing of the curriculum" to just academically oriented content and disciplines (Bruininks, Thurlow, \& Ysseldyke, 1992).

\section{Performance Standards}

The question of "How good is good enough?" is addressed in the setting of performance standards. As reported by the National Council on Education Standards and Testing (NCEST), student performance standards "establish the degree or quality of student performance ... set out in the content standards. In general, the development of such standards will require examples of a range of professionally judged student performances which serve as benchmarks for assessing the quality of a new student's performance" (National Council on Education Standards and Testing, 1992, p. E-4).

Performance standards will be used to describe the achievement of students, and for decision making at many levels. For the individual student, performance standards might define how good is good enough for him or her to: (a) progress from one grade to the next, (b) graduate with an endorsed diploma, or (c) be certified as competent in a given subject or field. Performance standards are used at the state level to produce a state report card that describes how students across the state and within school districts are performing in certain content areas. Some states (e.g., Maryland) already are publishing such a report; however, the reports will change as new performance standards are defined in relation to new content standards. Some authors (Porter, 1993; Selden, 1992) make a distinction between studentlevel and system-level performance standards. The difference is basically one of how many students are assessed, or what comparisons are made. Nonetheless, performance standards will be aligned with test data.

\section{Delivery Standards}

How will the nation be assured that its students are having a fair chance to meet the performance standards that measure achievement of the content standards? The answer is that another type of criteria, delivery standards, will be developed to "assess the quality of a school's (or district's) capacity and performance in educating its students" (National Council on Education Standards and Testing, 1992, p. E-5). Delivery standards are most like the inputs and processes that traditionally have been the focus of quality education discussions. Inputs include, of course, the funding for educational programs, the personnel, and the materials used to present the curriculum. "Process" essentially means the quality of the teaching that goes on in schools. In fact, an established standards-setting body for the field of teaching already exists: The National Board for Professional Teaching Standards (NBPTS). This group was formed in 1987 to develop national certification standards for what accomplished teachers should know and be able to do. Currently, the NBPTS is planning to grant certifications according to developmental level of expertise (e.g., early childhood to adult education). Teachers will have to demonstrate competence to the Board through evidence that may include: classroom observation, videotape records of teachers' work, portfolios, and national examinations on the specific content area (McLaughlin, 1993).

In addition, several individual content areas (e.g., mathematics and science) have published or will be publishing teaching standards specific to their discipline. The Professional Standards for Teaching Mathematics (National Council of Teachers of Mathematics, 1991) presents the vision of what teachers should know about mathematics, what the teaching of mathematics should entail, and how teaching should be evaluated (National Council of Teachers of Mathematics, 1991, p. vii). The standards developed for science also will include standards for teachers' professional development so teachers may gain and maintain skills and knowledge. The bottom line of teaching standards, as part of delivery standards, is to provide a mechanism for ensuring the schools' capacity to teach students up to the level of desirable competence.

Currently, one of the catch phrases of standards setters and policy makers in the present administration is "opportunity-to-learn (OTL) standards." Opportunity-to-learn standards are really delivery standards that will describe what service delivery should look like at the national and state levels. Specifically, OTL standards will present the expectations for the "conditions of teaching and learning that establish a basis for providing students with a fair opportunity to achieve the knowledge and skills prescribed by the ... national content standards" (U. S. Congress, 1993, p. 37). OTL standards are thought to be necessary complements to content and performance standards because without them "all of the consequences of inadequacies and inequities in curriculum, instruction, and learning environments would be assumed by students rather than schools and school systems" (Traiman \& Goren, 1993, p. 4). Given this perspective, the issue arises of how the OTL standards are to be used-for school and instructional improvement, or for accountability purposes. 
The National Governors' Association (NGA) has emphasized the improvement focus on OTL standards. Porter (1993) suggested that school accountability is the most sensible function that can be served by OTL standards. However, there is some concern that OTL standards, which are essentially inputs and processes, detract from the focus on student outcomes that is at the heart of the overall standards movement. Improvement and accountability do not have to be mutually exclusive uses of OTL standards. Still, holding schools accountable for both process and outputs presents a seemingly conflicting purpose of these efforts. At this time, OTL standards are being discussed only in voluntary terms. Results from assessments of the performance standards may change this viewpoint if students or schools are not meeting the expectations that are set.

\section{Other Terminology}

Although we have tried to define and explain the concept of "standards," there is still confusion in the "Babel of Standards" terminology used by different groups (Harvard School of Education, 1993, p. 1). Other types of standards that are discussed sometimes include "assessment standards," "evaluation standards," "policy standards," and "program standards."

The first two are used most often in discussions of the measurement of results of schooling. New tests and assessments of educational outputs are part of most reform efforts, and there is a need to address the extent to which these assessments are reliable and valid for their intended purpose. Many of the content-area standards efforts shown in Table 3 are including standards for assessment or evaluation, or both, as part of their overall plans. In addition, the American Psychological Association and the National Council on Measurement in Education are about to revise the Standards for Educational and Psychological Testing. These standards frequently are cited in court decisions and are used by many groups as guidelines for testing decisions. Rapidly evolving assessment strategies have outpaced the utility of the existing standards. The updated testing standards must reflect a renewed concern for fairness, recent public policy changes (e.g., Americans with Disabilities Act of 1990), and the ways in which the results of new tests are used ("National Testing," 1993).

Policy and program standards sometimes are mentioned in relation to the extent to which systems of education can be described or interact with one another. These standards are concerned more often with the big picture of how the other types of standards are to be implemented and often the specifics of "program" standards sound a great deal like delivery or OTL standards.

\section{EXAMPLES OF STANDARDS SETTING IN CURRICULAR AREAS}

Beyond the basics of what standards are about, one must recognize that the process of establishing national standards is a highly political and complex enterprise. To appreciate the extensiveness of such an undertaking more fully, it may be helpful to see the various sections and the framework of a standards document. We encourage you to examine the products of any standards group listed in Table 3. For now, we will describe in some detail the standards that have been published for mathematics and those being developed in science. Most national policy makers view the math effort as the best model for other standards activities to follow (National Education Goals Panel, 1993).

\section{Mathematics}

One of the most important and well known standards-setting efforts was that of the National Council of Teachers of Mathematics (NCTM). NCTM really started the current rush to publish standards in 1989, when it published the Curriculum and Evaluation Standards for School Mathematics (Standards) (National Council of Teachers of Mathematics, 1989). The Standards were developed over 4 years and are based on the "informed vision of what should be done, given current knowledge and experience" (National Council of Teachers of Mathematics, 1989, p. 5). They were developed to provide guidance to the field in reaching toward the national goal that American students would be first in the world in math and science by the year 2000. The Standards were based on several perceived needs of the nation:

Mathematically literate workers

Opportunity to learn mathematics for all students

$\square$ Problem-solving skills that serve lifelong learning

Each of these needs reflects the changing global society in which today's students will participate as adults. As such, the authors of the NCTM Standards believed the mathematics that will be needed by tomorrow's citizens should emphasize "doing" rather than simply "knowing that" (Crosswhite, 1990, p. 460).

The process standards of problem-solving, reasoning, communicating, and connecting mathematics are really at the heart of what NCTM believes students should be taught. 
Table 4 is a listing of the Curriculum and Evaluation Standards from NCTM. At each of the three grade levels used to organize the content standards, the four process standards are identical. As Crosswhite (1990) describes it, "The first four . . . standards . . . are illustrative of the flavor and spirit of the Standards" (p. 462).

These cornerstone standards are supplemented with approximately 10 additional standards within each grade-level breakdown. Some of the standards are repeated or somewhat modified at different levels, whereas others are contained within a level. NCTM intends that all students be held to the same standards and expectations prior to grade 9 . The 9-12 standards are differentiated with a core curriculum for all students and an extended program for collegebound students (Crosswhite, 1990).

To help teachers implement instruction that supports the Standards, NCTM published a companion series known as the Addenda Series (Burton et al., 1991). The Addenda Series is being used to clarify and illustrate the message of the four process standards. Activities that support the main themes of the standards are described for levels $\mathrm{K}-4,5-8$, and 9-12. Teachers are provided with:

TABLE 4

NCTM Curriculum and Evaluation Standards for Mathematics

Grades K-4
1. Mathematics as Problem Solving

2. Mathematics as Communication

3. Mathematics as Reasoning

4. Mathematics as Connections

5. Estimation

6. Number Sense and Numeration

7. Concept of Whole Number Operation

8. Whole Number Computation

9. Geometry and Spatial Sense

10. Measurement

11. Statistics and Probability

12. Fractions and Decimals

13. Patterns and Relationships

\section{Curriculum Standards}

Grades 5-8

Grades 9-12
1. Mathematics as Problem Solving

2. Mathematics as Communication

3. Mathematics as Reasoning

4. Mathematics as Connections

5. Algebra

6. Functions

7. Geometry from a Synthetic Perspective

8. Geometry from an Algebraic Perspective

9. Trigonometry

10. Statistics

11. Probability

12. Discrete Mathematics

13. Conceptual Underpinnings of Calculus

14. Mathematical Structure

\section{Evaluation Standards}

K-12

General Assessment

Student Assessment

Program Evaluation

1. Alignment with Curriculum

2. Multiple Sources of Information

3. Appropriate Assessment Methods and Uses
4. Mathematics Power

5. Problem Solver

6. Communication

7. Reasoning

8. Mathematical Concepts

9. Mathematical Procedures

10. Mathematical Disposition
11. Indicators for Program Evaluation

12. Curriculum and Instructional Resources

13. Instruction

14. Evaluation Team 
$\square$ Sample lessons that develop concepts

Activities that connect models and manipulatives with concepts and with mathematical representations

$\checkmark$ Problems that exemplify the use and integration of technology

Teaching approaches that promote reasoning skills, and approaches to evaluate student progress

Teachers of mathematics will require some time to incorporate most of the ideas emphasized by the Standards in their daily instructional practices. A survey of math teachers conducted for NCTM (Horizon Research, 1992) revealed that most teachers were not successfully adopting strategies consistent with the Standards, even though the Standards had received widespread acceptance at the administrative level. Most teachers continued to emphasize skill competencies (e.g., computation and algorithmic manipulation) over the processes of problem solving, reasoning, communication, and connections.

One of the key features of the math Standards is that they do challenge the way in which most students are taught mathematics. The major thrust of NCTM's public relations efforts to sell the Standards rests on the hope that a major paradigm shift can be effected in the way teachers think about math education. The essence of the Standards is their constructivist orientation, one in which students come to acquire mathematical knowledge by constructing appropriate knowledge structures for themselves (Romberg, 1990). The emphasis of teaching is on the meanings and appropriate use of operations, problem solving, and reasoning. Less attention is warranted for arithmetic computation and fluency with algorithms. These ideas are at odds with what many people think of when they think of math education, especially the education of students with disabilities. As Romberg concluded, "the notion that mathematics is a set of rules and formalisms ... [that] everyone is to use ... to obtain unique, correct answers must be changed" (p. 472).

One must be cautioned not to overreact to the problemsolving orientation of the Standards. Rote memorization of procedures without understanding is not a sufficient learner outcome. Nevertheless, a balance of teaching approaches that includes direct instruction of skills that enable students to approach problem-solving activities meaningfully is important. As Baker (1992) concluded in a discussion of current reform practices, student performance on higher-level tasks is not about doing things at the expense of knowing things.
The issue that arises for special educators is that the Standards seem far removed from their training and practice. Although NCTM includes the term "all students" quite often, it does not mention the learning needs of students with disabilities (Hutchinson, 1993; Rivera, 1993). Students with disabilities, however, do need better mathematical instruction than most are receiving. Authors such as Carnine, Dixon, Kameenui, and Silbert (undated) and Hofmeister (1993) contend that what is needed is a systematic and programmatic translation of the challenges presented in the Standards into usable, concrete teacher practices at the classroom level. Otherwise, the Standards are not likely to be truly transformed from a politically charged reform initiative into an educationally productive plan of action for all American students.

\section{Science}

The National Committee on Science Education Standards and Assessment (NCSESA) is preparing a comprehensive set of content, teaching, and assessment standards. NCSESA is coordinating concurrent efforts by working groups in each area to ensure consistency among the standards. Recently, another effort to develop standards for programs and policies was initiated to address implementation issues after the three major areas are finalized. All of these efforts rest on the decision of NCSESA to commit its work to providing science for all students. This decision was summarized in a progress report as follows:

\begin{abstract}
We emphatically reject the current situation in science education where members of populations defined by race, ethnicity, economic status, gender, physical disability or intellectual capacity are discouraged from pursuing science and excluded from opportunities to learn science. By adopting the goal of science for all, the standards prescribe the inclusion of all students in challenging science learning opportunities and define a level of understanding that all should develop. (National Committee on Science Education Standards and Assessment, 1993, p. 1)
\end{abstract}

NCSESA has sought direct input from scientists with disabilities and persons familiar with disability issues. These commitments illustrate a broadening of views by those who are setting standards to be more inclusive in their approach and recommendations for science education in the nation's schools (Hoffman \& Stage, 1993).

\section{Content Standards}

The content standards for science are organized into four general categories: 
Science as inquiry

$\square$ Science subject matter

Scientific connections

Scientific and human affairs

Inquiry is stressed as the heart of science education, and standards for inquiry include: (a) knowing about science as inquiry, (b) conducting scientific inquiries, and (c) developing component skills and habits of mind. With an emphasis on investigative behavior, the standards will reflect science as it is practiced in the real world. The skills of reasoning and problem solving are stressed as each domain of subject matter is explained through "representative inquiry" (National Committee on Science Education Standards and Assessment, 1993).

Subject matter standards will focus on the fundamental understandings of science that students should receive in their science education experiences. The domains most likely to be used as organizers include: physical sciences, earth and space sciences, and life sciences. NCSESA has been careful to stress that these organizers are suggested categories and that they do not imply any preferred organization for local science curricula. The format of the fundamental understandings to be included is uncertain at this time, but it most likely will be a narrative explanation of the substance of subject matter standards (National Committee on Science Education Standards and Assessment, 1993). Finally, standards for scientific connections and science and human affairs are included to emphasize the implications of the practice of science from multiple perspectives including: mathematical, technological, personal, civic, and historical.

\section{Teaching and Assessment Standards}

The working group on teaching standards for science has focused on three major concerns: the structure of science teaching, skills and knowledge essential for teachers of science, and ongoing professional development. The teaching standards affirm that students with diverse learning needs are, and should be, part of science education programs. Most of the working group's progress report describes how the process of teaching translates to meaningful experiences for all students. As such, a balanced approach to teaching individual students, which includes strategies ranging from direct instruction to free inquiry, is advocated and will be defined further in later efforts by the working group (National Committee on Science Education Standards and Assessment, 1993).
Assessment standards developed by another working group define the broad principles essential for exemplary assessment practice. Specific procedures for measuring progress toward the content standards will be included when the latter are complete. Currently, the working group has five standards under development:

Assessment in the service of learning from the student's perspective

Assessment in the service of teaching and learning from the teacher's perspective

- Assessment for decisions about individuals

Assessment for policy

$\square$ Assessment to monitor the system

To prompt discussion of assessment standards, the NCSESA working group on assessment presented a prototype showing its best current thinking on content and format for the first of its five standards: "Students have the opportunity to participate with teachers and share responsibility for formulating and constructing the assessment of their scientific learning and accomplishments" (National Committee on Science Education Standards and Assessment, 1993, p. 14). This standard was explained by providing (a) an elaboration of the background and precedent(s) for it, (b) a formal rationale, and (c) presuppositions and elaborations. An example from practice was to be developed, as were other assessment standards for teaching and learning, decision making, and policy evaluation and formulation.

\section{Linking Activities of Standards Groups}

Although national groups in each of the areas are developing standards, each group's product is not likely to look like that of any other group. Leaders of standards-setting groups met to discuss ways to approach their tasks consistently, but agreement was not reached even on the meaning of the term "standards" (Harvard School of Education, 1993). Therefore, we can be sure that discipline-specific standards will reflect the beliefs of experts and committees within those fields. We can be sure also, however, that the common thread among the efforts will be an emphasis on more challenging curricula. All standards-setting groups are emphasizing higher-order thinking, reasoning, and integrated problem solving.

The push toward higher standards also means that teachers within those disciplines will have to change what they do. Common to all efforts, then, is a need to rethink how instruction is delivered. In the field of mathematics, in which standards were published nearly 5 years ago, most math 
teachers still are teaching in the "old" way. Few of them emphasize higher-order thinking in their daily instruction, citing currently mandated curricula, assessments, and lack of training and support as reasons hindering more thorough implementation (Horizon Research, 1992). If we expect students to demonstrate competence in relation to newly proposed or adopted standards, the entire enterprise of educating students will have to change dramatically.

\section{ALTERNATIVE PERSPECTIVES ON STANDARDS AND THEIR USE FOR STUDENTS WITH DISABILITIES}

In many discussions about standards, a point of concern and contention often is how to include and address students with diverse learning needs. The issue is important for content, performance, and delivery standards. Most of the disciplinary setting standards have used inclusive language- that their standards are intended for all students. Yet, there are few certainties about how later phases of standards-related reform will include students with disabilities, students with limited English proficiency, and at-risk populations. Several alternative perspectives on the issues that arise in standards discussions are relevant, especially when implementation or uses of standards are at stake. The discussion here focuses on what might be done for students with disabilities. Considerations for other students probably are similar but are not addressed directly in this article.

\section{Excellence and Equity in Education}

The rhetoric surrounding standards efforts emphasizes that high content standards are important for "all" students. Two main premises underlie the push for higher standards in the educational system:

1. We need excellence at all levels of education.

2. Without direct attention to equity issues, excellence will be unattainable.

The need for excellence in education rests upon the clear indication that we will have to do a better job of preparing students to enter college or the workforce. Students will need the knowledge and skills required to participate as citizens in a technologically advanced world. These needs apply to all students, and "excellence" means that every student can and must learn to higher standards than currently are in place.

"Equity" in opportunities to attain higher standards is not a new issue. Darling-Hammond (quoted in Lockwood, 1993) concluded that past reform initiatives have revealed "glaring inequalities in opportunities nationwide" (p. 3). Current advocates of higher standards, however, maintain that as a nation we have no choice but to provide equitable opportunities that work for all students this time. Simmons (quoted in O'Neil, 1993) asserted that the need for excellence is a given, and that "we have to shift [all efforts] toward what resources we need to get everybody to meet these high standards" (p. 21). The challenge for those dealing with equity issues will be to avoid a cookbook approach that lists all required inputs for educational excellence. We must move away from doing the right thing to doing things right (Algozzine, Ysseldyke, \& Campbell, in press).

\section{Separate Standards for Special Education Students}

One option for setting standards is to establish supplementary or alternative standards for each area in which national efforts are underway. Creating separate standards might involve both content and performance standards, if a decision is made that attention must be paid to what is important to teach students with disabilities as well as how good is good enough on the performance end of standards. Alternatively, the argument can be made that only performance standards should be separated for special education. All students should be exposed to the same challenging curriculum, but a separate level of acceptable performance might be established.

The view that separate content standards are needed for special education raises the possibility that sets of categoryspecific standards are necessary. Separate special education content standards could be differentiated for all federally recognized disability classifications. In this line of thinking, 130 separate sets of content standards would be needed (10 content area standards times 13 disability categories). Standards also could be differentiated for selected disability categories or by differentiated functional levels or severity of disability. Indeed, almost any student characteristic could be presented as the basis for differentiated content standards.

Possibly, standards that are not aligned by curricular areas would be established for students with disabilities. Separate standards might be organized around concepts such as communications, functional literacy, and job/employability skills, rather than by content areas. Some sectors of the community are advocating such an approach for all students. Standards that are a set of clear expectations cutting across subject-area lines and emphasizing thinking and communication are preferable to discipline-specific standards 
(O'Keefe, 1993). In addition, if stakeholders in the education of students with disabilities were to decide to establish standards other than those presented by content areas, the format and organization of those standards might be quite different from any current effort.

Performance standards for students with disabilities could be differentiated along just as many dimensions. If students with disabilities were expected to receive instruction relative to established content standards but were held to separate performance standards, the decision of "how good is good enough" might be made relative to some characteristic of the student. Thus, if we assume homogeneity within category of disability, we might say, "Students with hearing impairments are to reach the $\mathrm{X}$ level of the $\mathrm{Z}$ standard, and those with emotional/behavioral disorders are to reach the $\mathrm{Y}$ level of the Z standard." Alternatively, we could use IQ or ability levels as the anchor point for differentiation of standards. Standards might be established according to the level of special education supports students receive. In this case, a relationship between the amount of time or type of special education and the level of performance required to meet a standard would be established.

Establishing separate standards because existing ones are considered inappropriate for any subset of students may serve to better define what stakeholders, including students, view as important curricular and performance expectations. Assessments of standards that are articulated around essential skills and competencies also may be more useful in defining and measuring the performance of students with disabilities. Much of the content in current standards may be inappropriate or irrelevant for students with disabilities (Shriner, Kim, Thurlow, \& Ysseldyke, 1992). Students with disabilities who participate in local, state, or national assessments often score at the lowest level of performance and experience significant pressure and frustration under these circumstances. Often they are excluded from the assessments (McGrew, Thurlow, Shriner, \& Spiegel, 1992). Parents, teachers, and principals often wish to avoid the testing procedure altogether (Center for Policy Options, 1993). Separate standards of performance (and accompanying appropriate assessments) may provide better data about the achievement and progress of students with disabilities.

By contrast, separate standards may serve to eliminate opportunities for students with disabilities in a number of ways. Separate content standards might narrow and limit the curriculum if instructional practices are geared toward only a select set of standards. At the extreme is the case in which a student with a disability may not be given the chance to pursue a specific area of interest because the "special education standards" do not address that topic. Separate standards, therefore, could be used as the basis for instructional delivery decisions that fit into a defined plan but are not in the student's best interest.

Separate performance standards, if they are lower than other standards, may unnecessarily lower the expectations held for students with disabilities. Krantz (1993) laments the widely held belief that "expectations for special education students are so low that no one bothers to collect evidence that these children are learning, or not" (p. 38). Differentiated performance standards and low expectations are likely to promote the tracking, inhibit the achievement, and diminish the self-concept of students with disabilities (Center for Policy Options, 1993; Lockwood, 1993).

Excluding students with disabilities from standards activities also perpetuates the myth of inherent differences between general and special education and continues the division among programs. Separate standards would help to reestablish the concept of separate but equal systems of education wherein students with disabilities may be excluded from schools, classroom, and other life experiences (Ysseldyke, Thurlow, Algozzine, Shriner, \& Gilman, 1993). In states or schools where standards are to be tied to graduation requirements (e.g., Minnesota), students held to separate standards may be required to accept an exit document or diploma different from that of students working on the "regular" standards. This sort of differentiation exists currently in many places. A larger effort (e.g., national standards) actually may serve to limit choices students have concerning their educational plans and programs.

\section{Progress Across a Range of Performance}

An alternate perspective to differing expectations or standards is to establish a single set of standards but expect a range of performance relative to them. When standards are set, students always perform at different levels relative to the standards. A priori recognition of this actuality may be a means to establish realistic and meaningful expectations for the full range of students educated in today's schools. Over time, the key indicator of progress toward better results is the progress of students toward higher standards relative to a certain baseline, perhaps their personal baseline. The ultimate goal is achievement of the standards for all students. In the interim between establishment and achievement of standards, however, the expected range of performance is monitored for different students or student groups. Improvement 
over time toward set standards, but interpreted through initial performance or developmental level, presents an opportunity to include all students in efforts to adopt national standards.

\section{Systemwide Improvement}

For many years the automobile industry has sought to improve the performance and fuel efficiency of the cars and trucks it produces. One standard this industry uses is the $a v$ erage miles per gallon (mpg) for its vehicles. Certainly, not all cars have improved in mpg ratings at the same pace (a gas guzzler is still a gas guzzler). The federal government, however, has required car manufacturers to improve the efficiency of every size of car, thus raising the average performance industry-wide. For standards within the system of education, an analogous option could be presented in which a systemwide average standard is set and improvement for all student groups is required. High standards could be established, and schools or districts expected to improve the average performance of its students each year.

The state of Kentucky incorporates some of these ideas in its state accountability system. Schools are required to demonstrate a specific increase (e.g., 1\%) in performance as indicated by the number of students who successfully meet certain standards, including academic and nonacademic outcomes. All students are included in this process. Students with disabilities who do not take the regular statewide assessment are given the chance to demonstrate their achievement in an alternative portfolio format. Their scores on the portfolio are included in the school's accountability index (Ysseldyke, Thurlow, \& Shriner, 1992).

The use of an average as a standard does not guarantee that all students will be expected to show gains. Educators may look for means to improve significantly the performance of students at the margins (Thurlow, 1993). The intent of raising standards for all students and schools, however, is to improve student performance across the board. Although every student may not show improvement, every segment of the school population is expected to improve. Goals 2000 contains the following language to this point: "The academic performance of elementary and secondary students will increase significantly in every quartile" (U. S. Senate, 1993, p. 10). Report language to support this legislation encourages educators to examine how students in every quartile can benefit from instruction geared toward the high standards set for all students.
Evaluations of progress toward the national goals will be looking for improvement covering the full range of students in today's schools (U. S. Congress, 1993). O'Keefe (1993) has stressed that an important task yet to be faced is that of developing meaningful ways for students functioning at a wide range of levels to show competence or improvement at various points in time relative to any set of standards. Every student must be afforded the opportunity to demonstrate the progress he or she has made toward achieving skills and standards important for their future as citizens in our society (Shriner, Ysseldyke, Thurlow, \& Honetschlager, in press).

\section{IEPs as Standards}

The individualized education plan (IEP) is the cornerstone of the special education programs that are provided to nearly 5 million students in America's schools. Some see the IEP itself as the primary safeguard of the rights guaranteed by the Individuals with Disabilities Education Act (IDEA) (Ysseldyke \& Algozzine, 1990). The IEP contains most of the essential elements of standards (goals, timelines, teaching, assessment, and evaluation strategies). Thus, the IEP is really the individual's standards and accountability system. A possible approach to address the broader standards issue is to build upon the IEP as a document and process in linking the special education student's program to school, district, state, or national goals and outcomes.

For the core subjects addressed in the national goals, the U. S. Department of Education Office of Special Education Programs presented an opinion stating in part that the IEP is an essential tool in addressing the needs of students with disabilities. Hanley (1992, p. 2) emphasized the following two points:

1. Students with disabilities will obtain maximum benefit from instruction in core subjects and skills pursuant to a carefully planned IEP.

2. Instruction in core subjects should be matched to standards based on each student's needs, not to one standard.

This approach employs the concept of "personal best," in which students are expected to achieve progressively higher outcomes than they presently are achieving. The IEP team is the link between the student's program and standards set by national groups, states, and districts, and translates these into a set of meaningful and realistic goals for the individual. This approach is reiterated in proposed federal legislation, which states: 
The IEP required by Part $\mathrm{B}$ of IDEA provides a mechanism for establishing goals and objectives that are individually determined, represent high expectations, and acknowledge a student's unique learning characteristics and current level of performance. (U. S.

Senate, 1993, p. 24)

The challenge of this approach is to prepare IEPs that are, in fact, aligned with goals and standards. The connections between the content of the IEP and standards must be made explicit. Outcomes that cover core subjects and unique learner needs (i.e., regular and special education outcomes) will be essential and must be documentable (L. Hargan, personal communication, Nov. 5, 1992). Tyler (quoted in Meek, 1993) eloquently summarized the essence of the "IEP as standards" approach as follows: "What you should do is encourage people to set the highest possible standards for themselves" (p. 86).

\section{WHAT HAPPENS NEXT? THE NATION'S DIRECTION}

\section{Goals 2000: The Educate America Act}

Most of the ideas behind current educational reform were presented by the Bush Administration in its program, America 2000. The Clinton Administration has reworded the basics of the reform into the proposed legislation of Goals 2000. The legislation focuses on raising standards for all students and promoting reforms that help revitalize American schools and preserve national economic strength (U. S. Congress, 1993). The bill has two versions, one by the House of Representatives (H. R. 3210) and one by the Senate (S. 1150). Both bills contain the same basic elements:

Enacting the six national education goals as law

Establishing a national committee to oversee standards efforts and approve state activities

Encouraging and supporting state efforts for standards

Establishing national skill standards to define what workers need to know

The four titles included in both versions of the bill are listed in Table 5. The first provision (Title I) restates the challenging goals for American education proposed jointly by President Bush and the National Governors' Association in 1989. Much attention since that time has focused on goals for students in academic subjects (English, math, science, history, and geography). As we discussed earlier, efforts to set standards in other subject areas (e.g., civics, the arts) also are underway. Less attention has been paid to goals such as Goal 6-safe, disciplined schools (Porter, 1993). The House version would add a goal to the law aimed at the ongoing professional development of teachers. Regardless of which version finally is adopted, Title I focuses national efforts to assure that all American students meet the challenges of a world economy, civic responsibility, and the national education goals.

\section{TABLE 5 \\ Major Sections of Goals 2000: Educate America Act}

\section{Title I National Education Goals}

Makes the six national education goals and their objectives official federal policy:

- All children in America will start school ready to learn

- The high school graduation rate will increase to at least 90 percent

- American students will be competent in all core academic subject

- American students will be first in the world in science and mathematics

- Every adult American will be literate and possess the skills necessary to compete in a global economy

- Every school in America will be safe, disciplined, and drug-free

Title II National Education Reform, Leadership, Standards and Assessment

Sustains the National Education Goals

Panel (NEGP) that oversees progress toward goals

Establishes a National Education Standards and Improvement Council (NESIC) that would approve national voluntary standards and states' standards (content, performance, and delivery)

Title III State and Local Education Systemic Improvement

Supports statewide and local reform efforts for funding, standards, and teacher development

\section{Title IV National Skills Standards Board}

Establishes and funds a national board to develop job skills standards 
Title II of the Act establishes the oversight procedures for all reform efforts. First, the National Education Goals Panel (NEGP) would be maintained. NEGP consists of governors, federal law makers, and officials for the Executive Branch, and issues an annual progress report on national education goals. Second, a National Education Standards and Improvement Council (NESIC) is to be established in accordance with the recommendations of an earlier federally sponsored task force, the National Council on Education Standards and Testing. The composition of NESIC remains to be determined, but it will include educators, business and community leaders, civil rights advocates, and persons with disabilities or familiar with disability issues. The responsibilities of NESIC revolve around all standards activities, and H.R. 3210 authorizes the Council to approve national standards. The Senate version places the approval process under the NEGP.

Both versions authorize NESIC to approve state-developed standards that are submitted voluntarily for the Council's certification. Although no changes in federal funding to states are tied to NESIC certification of state standards, states probably will seek the NESIC stamp of approval to lend credibility to the curricula (Hoff, 1993). Emphasizing the voluntary nature of standards certifications is important, because many people believe Goals 2000 may lead to the extreme overregulation of education by the federal government. Additional layers of bureaucracy do not guarantee student achievement, and most states strongly objected to early versions of the bill that tied funding to "approved standards activities" (National Governors' Association, 1993).

One of NESIC's main objectives will be to tackle the issue of opportunity-to-learn (OTL) standards. The task of creating an education delivery system that enables all students to achieve high standards will remain a state responsibility. NESIC, however, will oversee the development of processes by one or more work groups and will certify a set of national, voluntary OTL standards. Section 213(c) of S. 1150 outlines essential characteristics of the OTL standards that NESIC may certify, including the provision of highquality curriculum and instructional materials, capable teachers and administrators who continue their professional development, and alignment of curriculum, instructional practices, and assessments with the content and performance standards that are adopted.

Opportunity-to-learn standards are intended to level the playing field for all students. Some concern has been voiced that the focus on results is diminished by including provisions for inputs and processes. Both versions of the bill stress that our system must examine how other nations guar- antee students the chance to meet challenging standards. Simply raising standards without backing the efforts of states and schools to create conditions conducive to better student performance would not ensure attainment of any of the goals in Goals 2000 (National Governors' Association, 1993).

Finally, Title II directs NESIC to certify assessments used to monitor student progress. NESIC would develop assessment standards. The Council would look at how assessments are aligned with content standards, include multiple measures of performance, and provide for the participation of all students, including students with diverse learning needs. The assessments must be used to evaluate levels of achievement and progress toward the goals. The House version stipulates that state assessments may be approved only if the state has OTL standards or if the tests are not used for decisions affecting individual students' grades or progress through the educational system.

Title III of the bill, State and Local Education Systemic Improvement, is the funding heart of the legislation. States and local agencies would receive federal money (grants) to support reform efforts that are part of a comprehensive improvement plan. States would be required to establish guidelines for the distribution of funds to school districts, timetables for all types of standards, and the protection of local (or bottom-up) reform activities. States may voluntarily submit standards they set to NESIC for certification. Local schools may form cooperatives or consortia to support the development and implementation of reform plans. The emphasis of local efforts is to be on the continued professional development of teachers and administrators to support systemic reform. States and local agencies are challenged to involve parents and business and community leaders in planning the course of their efforts.

Title III also includes provisions for strengthening teacher training in institutions of higher education and encourages the collaboration of states and local districts with teacher training programs. Title III establishes waivers for districts or states from regulatory requirements of programs (e.g., Chapter I, Vocational Education) if the Department of Education is assured that a waiver does not hinder efforts to make progress toward improved student achievement. Finally, states would be required to present annual reports on their efforts to meet their goals.

Title IV of Goals 2000, known as the National Skills Standards Act, authorizes and funds the National Skills Standards Board discussed earlier. The Board is to develop job skill standards that would define what individuals entering the nation's workforce should know and be able to do and 
would consist of representatives from labor and education, as well as community members and advocates for minorities, persons with disabilities, women, and senior citizens. Efforts to set national skill standards would be organized around occupational clusters and would be coordinated with the work of standards groups for content areas and NESIC.

\section{FUTURE ISSUES FOR SPECIAL EDUCATION}

The National Center on Educational Outcomes (NCEO) provided written reports to the U. S. Congress concerning Goals 2000 and students with disabilities. Much of the input from NCEO was included in the Senate's report language in a special section devoted entirely to application of the law to individuals with disabilities (U. S. Congress, 1993, pp. 19-26). The overarching theme of this section is that Goals 2000 intends standards-setting groups to live up to their often-used rhetoric that their efforts are applicable to "all students." National, state, and local systemic change is expected for all programs serving all students. There must be consistency in the effort to raise the performance of the entire population toward higher standards. Standards are not a "general education" phenomenon.

\begin{abstract}
In far too many districts around the country, two separate educational systems have developed with little or no coordination - one system for regular or general education and a separate and distinct system for special education. This isolation and lack of coordination creates artificial barriers to achieving the promises of Part B of IDEA, the ADA, and Section 504 of the Rehabilitation Act of 1973. (U. S. Congress, 1993, p. 20)
\end{abstract}

Because Goals 2000 is intended to be consistent with existing laws upon which services to students with disabilities are based, the report demonstrated a commitment to including these students. Most notably, NESIC, the body overseeing all standards activities, must include among its members individuals with knowledge of and experience in educating and assessing students with disabilities. And, for content, performance, or opportunity-to-learn standards submitted to NESIC by national groups or states to be approved, issues of disability must be addressed adequately in light of existing law. Specifically:

The Committee intends that the exclusion of individuals with disabilities from any aspect of ... reform is unacceptable.... [There is] an expectation that all students across a broad range of performance will be held to high standards if they are to achieve to their full potential. (U. S. Congress, 1993, p. 20)
Reform efforts must give students the appropriate opportunities to meet high content standards, including the adoption of flexible teaching strategies and educational planning to make standards meaningful. In this regard, the IEP provides a possible mechanism to establish goals and objectives representing higher personal standards for students with disabilities. A large gap exists between the development of standards and the eventual assessment of progress. Special educators have the opportunity to demonstrate the implementation of adaptable instructional strategies and methods that assist students who often represent the greatest challenges in both academic and social-behavioral domains. Our job as educators, then, is to identify the factors that are hindering a given student from reaching the outcome and to search for the necessary accommodations and strategies that will move that student forward.

As major national groups and most states finish their standards development activities, many issues are on the horizon. Most notable, of course, is the implementation issue discussed above. As a nation, however, we are going to have to tackle the issues that will arise if students fail to meet the standards that we set. Consider the just released 1993 National Education Goals Report, which contains data indicating that at no point in their school careers do students meet adequate mathematics or reading proficiency levels of the National Assessment of Educational Progress (National Education Goals Panel, 1993). Officially, the report calls students' achievement "modest progress" toward the goals, but neither academic nor social-behavioral target goals likely will be reached by 2000 (Viadero, 1993).

Many people expected the lack of progress. Council of Chief State School Officers Director Gordon Ambach (quoted in Viadero, 1993) pointed out that "we've had these alarm bells for four or five years now and the issue is what action is to be taken" (p. 5). Among these issues and options, we offer the following to be considered by all teachers, administrators, and parents:

Should we adjust standards by (a) writing different ones for students who don't meet the original set, (b) lowering them so all students can meet them, (c) broadening them so some students can meet some standards, or (d) deleting the standards that nobody reaches?

Should we exclude students we expect to fail assessments of progress toward standards, or should we ignore their assessment results?

Should we institute a system of rewards and sanctions for progress or lack of progress toward established 
standards, and to whom should we apply these rewards and sanctions?

$\square$ Should we rethink the way we teach the concepts and content of the standards, or should we alter the means by which we measure student achievement?

We know most about the exclusion of students with disabilities from standards activities and from assessments of educational outcomes. NCEO estimates that $40 \%$ to $50 \%$ of school-age students with disabilities are excluded from prominent national data collection programs such as the $\mathrm{Na}$ tional Assessment of Educational Progress. State-by-state exclusion rates ranged from $33 \%$ to $87 \%$. At the state level we know that 21 states include less than half of their students with disabilities in their statewide testing program (U. S. Congress, 1993).

Some states (e.g., Maryland, Kentucky) are beginning to explore alternative approaches to deal with unsatisfactory results from school accountability assessments. Both states have plans in place to shift or replace school personnel in locations where insufficient progress is demonstrated. At this point, the effectiveness of these actions is uncertain. Such courses of remediation, however, do show a real commitment to improving the outcomes of schooling for the students in those locales.

As the focus on outcomes and standards becomes clearer across the country, special educators must be attentive to the impact that actions at all levels have on the students they serve. Data on the extent to which students with disabilities are making progress toward established standards may be misunderstood or used to undermine the best of intentions and plans. The safeguards of services and educational and civil rights are not to be ignored or overridden because of a focus on outcomes. The Senate's report on Goals 2000 reinforced this point quite often. Rather, these provisions are to be seen as the groundwork from which all students are to be encouraged and supported to meet the challenges of higher standards.

\section{REFERENCES}

Algozzine, B., Ysseldyke, J. E., \& Campbell, P. (in press). Strategies and tactics for effective instruction. Teaching Exceptional Children.

Baker, E. L. (1992, November). Performance assessment: High hopes, high standards. Paper presented at Performance-Based Assessment: A National Perspective for the State of Minnesota, Minneapolis, Center for Applied Research and Educational Improvement (CAREI).

Bruininks, R., Thurlow, M. L., \& Ysseldyke, J. E. (1992). Assessing the right outcomes: Prospects for improving education for youth with disabilities. Education \& Training in Mental Retardation, 27(2), 93-100.
Burton, G., Clements, D., Coburn, T., Delgrande, J., Firkins, F., Joyner, J., Leiva, M. A., Lindquist, M. M., \& Morrow, L. (1991). First grade book: Curriculum and evaluation standards for school mathematics addenda series grades $K-6$. Reston, VA: National Council of Teachers of Mathematics.

Carnine, D. W., Dixon, R., Kameenui, E. J., \& Silbert, J. (undated). Expanding and enriching the mathematics curriculum to accommodate students with different needs and interest: Responding to the NCTM Curriculum Standards. Unpublished manuscript. University of Oregon, National Center to Improve the Tools of Educators.

Center for Policy Options. (1993). Issues and options in outcomes-based accountability for students with disabilities. Unpublished manuscript, University of Maryland.

Crosswhite, F. J. (1990). National standards: A new dimension in professional leadership. School Science \& Mathematics, 90, 454-465.

Hanley, T. (1992). World class standards in math and science for students with disabilities. Paper presented at annual meeting of Council of Exceptional Children, Baltimore.

Harvard School of Education. (1993). The push for new standards provokes hype and fear-and both are justified. Harvard Education Letter, 9(5), 1-5.

Hoff, D. (1993, October 7). House changes would make ‘Goals 2000' standards voluntary. Education Daily, 26(194), 1-2.

Hoffman, K. M., \& Stage, E. K. (1993). Science for all: Getting it right in the 21st century. Educational Leadership, 50(5), 27-31.

Hofmeister, A. M. (1993). Elitism and reform in school mathematics. Remedial and Special Education, 14(6), 8-13.

Horizon Research. (1992). The road to reform in mathematics education: How far have we traveled? Chapel Hill, NC: Author.

Hutchinson, N. L. (1993). Students with disabilities and mathematics education reform-Let the dialogue begin. Remedial \& Special Education, 14(6), 20-23.

Krantz, D. O. (1993, June 23). Separate is not equal. Education Week, 12(39), 38-40.

Lockwood, A. T. (1993). Investing in equity. Focus in Change, 11, 1-6.

McGrew, K. S., Thurlow, M. L., Shriner, J. G., \& Spiegel, A. (1992). Inclusion of students with disabilities in national and state data collection systems. Minneapolis: National Center on Educational Outcomes.

McLaughlin, M. (1993, July). Teaching and educational restructuring. Paper presented at Work Group on Educational Reform and Special Education, Washington, DC.

Meek, A. (1993). On setting the highest standards: A conversation with Ralph Tyler. Educational Leadership, 50(6), 83-86.

National Commission on Excellence in Education. (1983). A nation at risk: The imperative for educational reform. Washington, DC: U. S. Government Printing Office.

National Committee on Science Education Standards and Assessment. (1993). National science education standards: July '93 progress report. Washington, DC: National Research Council.

National Council on Education Standards and Testing. (1992). Raising standards for American education. Washington, DC: U. S. Government Printing Office.

National Council of Teachers of Mathematics. (1989). Curriculum and education standards for school mathematics. Reston, VA: Author.

National Council of Teachers of Mathematics. (1991). Professional standards for teaching mathematics. Reston, VA: Author. 
National Education Goals Panel. (1993). The national education goals report 1993: Vol. 1, The national report. Washington, DC: U. S. Government Printing Office.

National Governors' Association. (1993). Providing an opportunity to learn: Principles for states. Washington, DC: NGA Task Force on Education.

National testing standards to be revised. (1993). Educational Researcher, 22(7), 30

O'Keefe, M. (1993, September). Comments to the Technical Planning Group of the National Education Goals Panel (Public forum on education standards). St. Paul, MN: National Education Goals Panel.

O’Neil, J. (1993). On the New Standards Project: A conversation with Lauren Resnick and Warren Simmons. Educational Leadership, 50(5), $17-21$.

Olson, L. (1993, May 12). Skepticism, concern greet fast-track plan for skills standards. Education Week, p. 5, 20.

Porter, A. (1993). School delivery standards. Educational Researcher, 22(5), 24-30.

Rivera, D. M. (1993). Examining mathematics reform and the implications for students with disabilities. Remedial and Special Education, 14(6), 24-27.

Romberg, T. A. (1990). Evidence which supports NCTM's Curriculum and Evaluation Standards for School Mathematics. School Science \& Mathematics, 90, 466-479.

Secretary's Commission on Achieving Necessary Skills. (1992). Learning a living: A blueprint for high performance. Washington, DC: U. S. Department of Labor.

Selden, R. (1992). National standards and testing. State Board Connection: Issues in Brief, 12(4), 1-5.
Shriner, J. G., Kim, D., Thurlow, M. L., \& Ysseldyke, J. E. (1992). IEPs and standards: What they say for students with disabilities (Technical Report No. 5). Minneapolis: University of Minnesota, National Center on Educational Outcomes.

Shriner, J. G., Ysseldyke, J. E., Thurlow, M. L., \& Honetschlager, D. (in press). "All" means "All." Educational Leadership.

Traiman, S., \& Goren, P. (1993). Understanding opportunity to learn. Basic Education, 37(10), 5-10.

Thurlow, M. L. (1993, July). Outcomes in educational reform: Implications for involving all students in 'Goals 2000' communities. Paper presented at Work Group on Educational Reform and Special Education, Washington, DC.

U. S. Congress. (1993, July). Goals 2000: Educate America Act, Senate report 103-85 to accompany S. 1150, 103d Congress, 1st Session, Senate Committee on Labor and Human Resources.

U. S. Senate. (1993). Goals 2000: Educate America Act. S. 1150, 103d Congress, 1st Session.

Viadero, D. (1993, June 16). Guide to national efforts to set subject-matter standards. Education Week, pp. 16-17.

Ysseldyke, J. E., \& Algozzine, B. (1990). Introduction to special education (2nd ed.). Boston: Houghton-Mifflin.

Ysseldyke, J., Thurlow, M., Algozzine, B., Shriner, J., \& Gilman, C. (1993). National goals, national standards, national tests: Concerns for all (not virtually all) students with disabilities? (Synthesis Report II). Minneapolis: University of Minnesota, National Center on Educational Outcomes.

Ysseldyke, J. E., Thurlow, M. L., \& Shriner, J. G. (1992). Outcomes are for special educators too. Teaching Exceptional Children, 25, 36-50. 


\section{FOCuson

\section{Professional update}

\section{February 25-27, 1994}

California Association of Resource Specialists San Francisco Airport Marriott Hotel

San Francisco, CA

Contact: CARS, (916) 927-6296
April 6-10, 1994

CEC Annual Convention Colorado Convention Center Denver, CO

Contact: CEC, (703) 620-3660

\section{March 11-12, 1994}

Partnership Conference on Students with Learning Disabilities Perdido Beach Resort Orange Beach, AL

Contact: Sherri Savage

Livingston University

Livingston, AL 35470

\section{PERMISSIONS AND COPYRIGHT}

All rights are reserved. No part of this publication may be reproduced, photocopied, faxed, stored in a retrieval system, or transmitted, in any form or by any means, electronic, mechanical, recording or otherwise, without the prior written permission of the publisher.
Back issues are available for sale. Reproduction requires permission and payment of fees. It is illegal and a violation of Federal copyright law to reproduce this publication without permission. Direct all inquiries to the permissions editor. 